\title{
The Potentialof Renewable Energy: Using The Environmental Kuznets Curve Model
}

\author{
Jamalludin Sulaiman, Azlinda Azman and Behnaz Saboori \\ School of Social Sciences, University Sains Malaysia, Penang, Malaysia
}

Received 2013-01-24, Revised 2013-03-29; Accepted 2013-04-12

\begin{abstract}
This study examines the potential of Renewable Energy Sources (RES) in reducing the impact of carbon emission in Malaysia and the Greenhouse Gas (GHG) emissions, which leads to global warming. Using the Environmental Kuznets Curve (EKC) hypothesis, this study analyses the impact of electricity generated using RES on the environment and trade openness for the period 1980-2009. Using the Autoregressive Distributed Lag (ARDL) approach the results show that the elasticities of electricity production from renewable sources with respect to $\mathrm{CO}_{2}$ emissions are negative and significant in both the short and long-run. This implies the potential of renewable energy in controlling $\mathrm{CO}_{2}$ emissions in both short and long-run in Malaysia. Renewable energy can ensure sustainability of electricity supply and at the same time can reduce $\mathrm{CO}_{2}$ emissions. Trade openness has a significant negative effect on $\mathrm{CO}_{2}$ emissions in the long-run. The Granger causality test based on Vector Error Correction Mode (VECM) indicates that there is an evidence of positive bi-directional Granger causality relationship between economic growth and $\mathrm{CO}_{2}$ emissions in the short and long-run suggesting that carbon emissions and economic growth are interrelated to each other. Furthermore, there is a negative long-run bi-directional Granger causality relationship between electricity production from renewable sources and $\mathrm{CO}_{2}$ emissions. The short-run Granger causality shows a negative uni-directional causality for electricity production from renewable sources to $\mathrm{CO}_{2}$ emissions. This result suggests that there is an inverted U-shaped relationship between $\mathrm{CO}_{2}$ emissions and economic growth.
\end{abstract}

Keywords: Renewable Energy, Trade, Electricity Consumption, $\mathrm{CO}_{2}$ Emissions

\section{INTRODUCTION}

Carbon dioxide $\left(\mathrm{CO}_{2}\right)$ emissions are the major causes of Greenhouse Gas (GHG) emissions and global warming. The main source of $\mathrm{CO}_{2}$ emissions come from fossil fuels burning such as oil, gas and coal. Rapid depletion of fossil fuels and their negative impacts on the environment is slowly shifting the world economies towards using more sustainable renewable energy sources. Currently, the five main renewable energy sources are biomass, water (hydropower), geothermal, wind and solar. Except for biomass the other renewable energy sources can be regenerated, sustain and do not directly have negative impact on global warming and climate change.

Economic growth along with industrialization process bring a substantial increase in energy demand especially electricity. There are evidences of significant relationships between electricity consumption and economic growth (Ferguson et al., 2000; Ghosh, 2002; Shiu and Lam, 2004; Wolde-Rufael, 2004; Narayan and Smyth, 2005). Among the Association of Southeast Asian Nations (ASEAN) countries, Malaysia is second highest in terms of per capita electricity consumption. Based on available data, Malaysia's electricity consumption increased from $309.75 \mathrm{kWh}$ per capita in 1971 to $3911.85 \mathrm{kWh}$ per capita in 2009 (an increase of $1269 \%$ ). With the expected four percent (4\%) annual economic growth, it is estimated that Malaysia will consume electricity nearly twice the current level in 2020. In order to meet this increased demand of electricity and at the same time to minimize the negative environmental impacts of electricity generation and/or consumption, substantial effort and investment in Corresponding Author: Jamalludin Sulaiman, School of Social Sciences, University Sains Malaysia, Penang, Malaysia 
Renewable Energy Sources (RES) has been undertaken by the Malaysian government.

In 1981, Malaysia introduced the Four Fuel Diversification Policy after the first National Energy Policy 1971 and the National Depletion Policy 1980, to prevent the overdependence on oil as the main energy source especially in electricity generation. The country is well endowed with Renewable Energy Sources (RES) including forest residues, oil palm biomass, solar thermal, mill residues, hydro, solar PV, municipal waste, rice Husk and landfill gas (Koh and Hoi, 2002). In 2000, the Four Fuel Policy was amended and became the nation's Fifth Fuel Policy when Renewable Energy (RE) was announced as the fifth fuel in the energy mix. In 2006 the national biofuel policy was implemented to put more emphasis on biofuel consumptions in order to minimize the country's dependency on depleting fossil fuels sources and at the same time to meet the environmental related objectives.

Current literatures on environmental pollution, economic growth and energy consumption can be classified into three groups. The first group of studies focused on the relationship between environmental pollution and economic growth vis-à-vis the Environmental Kuznets Curve (EKC) hypothesis, which proposes a positive relationship between income and environmental degradation in the begining of economic growth and when the economy grows over time this relationship reverses, resembling an inverted U-shaped. Large number of literatures (Grossman and Krueger, 1991; Shafik and Bandyopadhyay, 1992; Panayotou, 1993; Roca et al., 2001; Shafik, 1994; Holtz-Eakin and Selden, 1995; Bruyn et al., 1998) used cross-section or panel data techniques to estimate the relationship between per capita income and various environmental indicators for a group of countries. Later researchers focused on individual country's analysis to test the relationship between economic growth and environmental pollution in a single country (Bruyn et al., 1998; Roca et al., 2001; Lindmark, 2002; Fried and Getzner, 2003; Egli, 2004; Akbostanci et al., 2009; Fodha and Zaghdoud, 2010; He and Richard, 2010; Saboori et al., 2012). However, the empirical evidence in support of positive, negative or an inverted U-shaped relationship between environmental degradation and economic growth has not been conclusive yet in both the panel and time series data based analysis.

The next group of literatures tested the relationship between economic growth and energy consumption. Since the seminal study by Kraft and Kraft (1978), many other studies have tested the relationship between energy consumption and economic growth in a bivariate model
(Ghosh, 2002; Soytas and Sari, 2003; Shiu and Lam, 2004; Yoo, 2005; Altinay and Karagol, 2005; WoldeRufael, 2005) and the relationship between energy consumption, economic growth and other explanatory variables such as labor, capital, technological changes in a multivariate framework (Stern, 1993; Masih and Masih, 1997; Asafu-Adjaye, 2000; Oh and Lee, 2004; Narayan and Smyth, 2005; 2009). The empirical results related to the relationship between economic growth and energy consumption or electricity consumption reveal that most of the researchers found a positive causality running from energy or electricity consumption to economic growth (Stern, 1993; Asafu-Adjaye, 2000; Oh and Lee, 2004; Shiu and Lam, 2004; Yoo, 2005; Altinay and Karagol, 2005). While Masih and Masih (1997) and Narayan and Smyth (2009) found a bi-directional causality between energy consumption and economic growth Soytas and Sari (2003) found no causality between the variables.

Due to the omitted variable biased which may embodied in the first and second group, the third group emerged to examine the relationship between environmental pollutants, economic growth, energy consumption and other explanatory variables such as labor, capital, urbanization and trade openness in a multivariate frame work (Sari and Soytas, 2009; Halicioglu, 2009; Jalil and Mahmud, 2009; Zhang and Cheng, 2009; Iwata et al., 2010; Ozturk and Acaravci, 2010; Ghosh, 2010; Menyah and Wolde-Rufael, 2010; Hossain, 2011; Nasir and Rehman, 2011; Shahbaz et al., 2012). They mostly tested the existence of EKC besides testing the causal relationship between environmental pollutants, economic growth, energy consumption and other variables. The results are quite mixed.

As an example EKC hypothesis has been supported by Iwata et al. (2010) in France, Jalil and Mahmud (2009) for China, Shahbaz et al. (2012) and Nasir and Rehman (2011) in Pakistan while other studies could not support the existence of EKC (Halicioglu, 2009; Ozturk and Acaravci, 2010 all for turkey; Menyah and WoldeRufael, 2010 for South Africa). Jalil and Mahmud (2009); Iwata et al. (2010) and Shahbaz et al. (2012) found a uni-directional causal relationship running from economic growth to $\mathrm{CO}_{2}$ emissions. Shahbaz et al. (2012) found that energy consumption increases $\mathrm{CO}_{2}$ emissions and trade openness reduces $\mathrm{CO}_{2}$ emissions in Pakistan. Iwata et al. (2010) included nuclear power generation to his multivariate model to investigate the existence of EKC for $\mathrm{CO}_{2}$ emissions in France. They found uni-directional causality running from economic 
growth, nuclear power generation, trade openness, urbanization and energy consumption to $\mathrm{CO}_{2}$ emissions. In their studies, they pointed out the importance of nuclear energy in reducing $\mathrm{CO}_{2}$ emissions.

The current study considers the relationship between $\mathrm{CO}_{2}$ emissions, economic growth, renewable electricity generation and trade openness in Malaysia. So far there is no known available study looking at renewable electricity generation in examining an inverted U-shaped relationship between environmental pollutants and economic growth and in determining the level of carbon dioxide emissions in Malaysia.

The remaining part of the study is organized as follows: Section 2 discusses the data and model, the econometric techniques are explained in section 3 . Section 4 reports the empirical results and discusses the paper and Section 5 concludes the study with a summary of the main findings and its policy implications.

\section{MATERIALS AND METHODS}

\subsection{Data}

This study uses annual time series data for Malaysia from 1980 to 2009. The study period was chosen based on the availability for all the data series. Real GDP per capita (Y) in constant $2000 \mathrm{US} \$, \mathrm{CO}_{2}$ Emissions (E) in metric tons per capita, total renewable Electricity net Production (ELP) per capita in Billion Kilowatt hours and Trade openness Ratio (TR) is the total value of real import and real export as a percentage of real GDP are employed in this study. All data are from the World Development Indicators (WDI) online database except the ELP was collected from U.S. Energy Information Administration (EIA). ELP from renewable sources includes hydropower, geothermal, solar, tides, wind, biomass, waste and biofuels. All the variables transformed to natural logarithms for the purpose of the analysis. We have used Microfit 4 and Eviews 7 to conduct the analysis. Table 1 summarizes the statistics of each of the variable used in the analysis.

\subsection{Model}

Following the recent empirical literatures such as Iwata et al. (2010) and Hossain (2011) it is possible to test the long-run relationship between $\mathrm{CO}_{2}$ emissions, economic growth, renewable electricity production and trade openness in a linear logarithmic quadratic form with a view of testing the validity of the EKC hypothesis using the following equation:

$$
\mathrm{E}_{\mathrm{t}}=\alpha_{0}+\alpha_{1} \mathrm{Y}_{\mathrm{t}}+\alpha_{2}\left(\mathrm{Y}_{\mathrm{t}}\right)^{2}+\alpha_{3} \mathrm{ELP}_{\mathrm{t}}+\alpha_{4} \mathrm{TR}+\varepsilon_{\mathrm{t}}
$$

Table 1. Descriptive statistics

\begin{tabular}{lrrrrr}
\hline Variables & \multicolumn{1}{c}{ Mean } & \multicolumn{1}{c}{ Median } & Maximum & Minimum & $\begin{array}{c}\text { Standard } \\
\text { deviation }\end{array}$ \\
\hline Y & 8.0607 & 8.1494 & 8.52869 & 7.55466 & 0.32273 \\
$\mathrm{Y}^{2}$ & 65.0760 & 66.4140 & 72.73860 & 57.07300 & 5.18710 \\
$\mathrm{E}$ & 1.4178 & 1.5449 & 2.02990 & 0.70510 & 0.45200 \\
ELP & 1.5016 & 1.6357 & 2.12298 & 0.25464 & 0.49609 \\
TR & 5.0557 & 5.1327 & 5.39548 & 4.63630 & 0.26880 \\
\hline
\end{tabular}

$\alpha$. E indicates per capita carbon dioxide emissions in metric tons, Y indicates per capita real GDP in constant 2000 US\$, ELP indicates per capita renewable electricity net production in Billion Kilowatt hours and TR indicates openness ratio

where, $\mathrm{E}$ is a per capita $\mathrm{CO}_{2}$ emissions, $\mathrm{Y}$ represents per capita real income, ELP stands for electricity production from the renewable source, TR represents trade openness and $\varepsilon_{\mathrm{t}}$ is the standard error term. Based on EKC hypothesis, the sign and value of $\alpha_{1}$ and $\alpha_{2}$ indicate different functional forms. When $\alpha_{1}=\alpha_{2}=0$, this indicates a level relationship, when $\alpha_{1}<0$ and $\alpha_{2}=0$, this indicates a monotonically decreasing linear relationship, when $\alpha_{1}>0$ and $\alpha_{2}=0$, this indicates a monotonically increasing linear relationship, when $\alpha_{1}<0$ and $\alpha_{2}>0$, this represents U-shaped relationship and when $\alpha_{1}>0$ and $\alpha_{2}<0$, this indicates an inverted U-shaped relationship, hence the EKC. In this case peak emissions per capita is $\mathrm{Y}^{*}=\alpha_{1} / 2 \alpha_{2}$. As the variable $\mathrm{Y}$ in this study is measured in logs, then $\exp \left(\mathrm{Y}^{*}\right)$ will yield the monetary value representing the turning point or the peak of the EKC. Since renewable energy could be a factor leading to decrese decrease of $\mathrm{CO}_{2}$ emissions, $\alpha_{3}$ is expected to be negative. The expected sign of trade openness coefficient is mixed. If the productions of pollutant intensive goods are limited due to the environmental regulation, $\alpha_{4}$ is expected to be negative.

\subsection{Econometric Techniques}

\subsubsection{ARDL Bounds Testing of Cointegration}

An emerging area in energy economics is the test of the EKC hypothesis using the cointegration relationships between environmental degradation, economic growth and energy. The Autoregressive Distributed Lag (ARDL) approach suggested by Pesaran et al. (2001) was chosen for this study to examine the dynamic relationship between $\mathrm{CO}_{2}$ emissions, economic growth and electricity production in Malaysia. The ARDL framework of Equation 1 of the model is as follows:

$$
\begin{aligned}
\Delta \mathrm{E}_{\mathrm{t}}= & \alpha_{0}+\sum_{\mathrm{k}=1}^{\mathrm{n}} \alpha_{1 \mathrm{k}} \Delta \mathrm{E}_{\mathrm{t}-\mathrm{k}}+\sum_{\mathrm{k}=0}^{\mathrm{n}} \alpha_{2 \mathrm{k}} \Delta \mathrm{Y}_{\mathrm{t}-\mathrm{k}}+\sum_{\mathrm{k}=0}^{\mathrm{n}} \alpha_{3 \mathrm{k}} \Delta(\mathrm{Y})_{\mathrm{t}-\mathrm{k}}^{2}+ \\
& \sum_{\mathrm{k}=0}^{\mathrm{n}} \alpha_{4 \mathrm{k}} \Delta \mathrm{ELP}_{\mathrm{t}-\mathrm{k}}+\sum_{\mathrm{k}=0}^{\mathrm{n}} \alpha_{5 \mathrm{k}} \Delta \mathrm{TR}_{\mathrm{t}-\mathrm{k}}+\varphi_{1} \mathrm{E}_{\mathrm{t}-1}+ \\
& \varphi_{2} \mathrm{Y}_{\mathrm{t}-1}+\varphi_{3}(\mathrm{Y})_{\mathrm{t}-1}^{2}+\varphi_{4} \mathrm{ELP}_{\mathrm{t}-1}+\varphi_{5} \mathrm{TR}_{\mathrm{t}-1}+\varepsilon_{\mathrm{t}}
\end{aligned}
$$


where, $\alpha_{0}$ and $\varepsilon_{\mathrm{t}}$ is the drift component and white noise, respectively. $\alpha_{1}, \alpha_{2}, \alpha_{3}, \alpha_{4}$ and $\alpha_{5}$ represent the error correction dynamics while $\phi_{1}, \phi_{2}, \phi_{3}, \phi_{4}$ and $\phi_{5}$ correspond to the long-run relationship in baseline Equation 2.

In the ARDL bounds testing approach the first step is to estimate Equation 1 by Ordinary Least Square (OLS). The bounds testing procedure is based on the joint $F$ statistic or Wald statistic to test the null hypothesis of no cointegration, $\mathrm{H}_{0}: \phi_{0}, \phi_{1}, \phi_{2}, \phi_{3}, \phi_{4}, \phi_{5}=0$ against the alternative of $\mathrm{H}_{1}: \phi_{0}, \phi_{1}, \phi_{2}, \phi_{3}, \phi_{4}, \phi_{5}=0$. The $F$-test is conducted to test the existence of long-run relationship among the variables. The critical values of the $F$-statistics in this test are available in Pesaran and Pesaran (1997) and Pesaran et al. (2001) (These critical values are generated for sample sizes of 500 and 1000 observations. Narayan (2005) argues that exiting critical values cannot be used for small sample sizes because these values were obtained based on large sample sizes. Narayan (2005) calculated critical values for small sample sizes. Given the small sample size in this study the critical values of Narayan (2005) for the bounds F-test are employed). There are two sets of critical values for a given significance level, with and without a time trend, one for $\mathrm{I}(0)$ variables and the other set for $\mathrm{I}(1)$ variables, which are known as Lower Bounds (LCB) and Upper Bounds Critical values (UCB) respectively. This provides a band covering all possible classifications of the variables into $\mathrm{I}(0)$ and $\mathrm{I}(1)$. If the computed F-statistic is higher than the UCB, the null hypothesis of no cointegration is rejected and if it is below the LCB the null hypothesis cannot be rejected and if it lies between the $\mathrm{LCB}$ and $\mathrm{UCB}$, the result is inconclusive. At this stage of the estimation process, the unit root tests are normally carried out on variables entered into the model. Once a long-run relationship has been established, Error Correction Model (ECM) can be estimated. A general ECM of Equation 2 is formulated as follows Equation 3:

$$
\begin{aligned}
\Delta \mathrm{E}_{\mathrm{t}}= & \delta_{0}+\sum_{\mathrm{k}=0}^{\mathrm{n}} \delta_{1 \mathrm{k}} \Delta \mathrm{E}_{\mathrm{t}-\mathrm{k}}+\sum_{\mathrm{k}=0}^{\mathrm{n}}+\sum_{\mathrm{k}=0}^{\mathrm{n}} \delta_{4 \mathrm{k}} \Delta \mathrm{ELP}_{\mathrm{t}-\mathrm{k}}+\sum_{\mathrm{k}=0}^{\mathrm{n}} \delta_{3 \mathrm{k}} \Delta(\mathrm{Y})_{\mathrm{t}-\mathrm{k}}^{2} \\
& +\sum_{\mathrm{k}=0}^{\mathrm{n}} \delta_{5 \mathrm{k}} \Delta \mathrm{TR}_{\mathrm{t}-\mathrm{k}}+\theta \mathrm{ECM}_{\mathrm{t}-1}+\varepsilon_{\mathrm{t}}
\end{aligned}
$$

The Error Correction Term $\left(\mathrm{ECT}_{\mathrm{t}-1}\right)$ indicates the speed of the adjustment and shows how quickly the variables return to the long-run equilibrium and it should have a statistically significant coefficient with a negative sign. To ensure the suitability of the model, the diagnostic and stability tests are also conducted. These include, testing for serial correlation, functional form, normality and heteroscedasticity associated with selected models. Pesaran et al. (2001) suggested estimating the stability of long and short-run estimate through Cumulative Sum (CUSUM) and Cumulative Sum of Squares (CUSUMSQ). Thus the stability tests such as CUSUM and CUSUMSQ are conducted in order to check the stability of the coefficient in estimated model.

\subsection{Granger Causality Analysis}

The cointegration approaches are employed to test the existence or absence of long-run relationship between variables. To test the direction of causality between carbon emissions, economic growth, electricity production from renewable source and trade openness the Granger (1969) approach based on the Vector Error Correction Model (VECM) is employed. The test answers the question of whether $\mathrm{x}$ causes $\mathrm{y}$ or $\mathrm{y}$ causes $\mathrm{x}$. $\mathrm{x}$ is said to be Granger caused by $\mathrm{y}$ if $\mathrm{y}$ helps in the prediction of the present value of $\mathrm{x}$ or equivalently if the coefficients on the lagged y's are statistically significant. In the presence of long-run relationship between variables in the model, the lagged Error Correction Term $\left(\mathrm{ECT}_{\mathrm{t}-1}\right)$ was obtained from the long-run cointegration relationship and was included in the equation as an additional independent variable. The following model was employed to test the causal relationship between the variables Equation 4:

$$
\begin{aligned}
& {\left[\begin{array}{l}
\mathrm{E}_{\mathrm{t}} \\
\mathrm{Y}_{\mathrm{t}} \\
\mathrm{ELP}_{\mathrm{t}} \\
\mathrm{TR}_{\mathrm{t}}
\end{array}\right]=\left[\begin{array}{l}
\lambda_{1} \\
\lambda_{2} \\
\lambda_{3} \\
\lambda_{4}
\end{array}\right]+\left[\begin{array}{l}
\mathrm{j}_{11,1} \mathrm{j}_{12,1} \mathrm{j}_{13,1} \mathrm{j}_{14,1} \\
\mathrm{j}_{21,1} \mathrm{j}_{22,1} \mathrm{j}_{23,1} \mathrm{j}_{24,1} \\
\mathrm{j}_{31,1} \mathrm{j}_{32,1} \mathrm{j}_{33,1} \mathrm{j}_{34,1} \\
\mathrm{j}_{41,1} \mathrm{j}_{42,1} \mathrm{j}_{43,1} \mathrm{j}_{44,1}
\end{array}\right]\left[\begin{array}{l}
\mathrm{E}_{\mathrm{t}-1} \\
\mathrm{Y}_{\mathrm{t}-1} \\
\mathrm{ELP}_{\mathrm{t}-1} \\
\mathrm{TR}_{\mathrm{t}-1}
\end{array}\right]} \\
& +\ldots+\left[\begin{array}{l}
\mathrm{j}_{11, \mathrm{k}} \mathrm{j}_{12, \mathrm{k}} \mathrm{j}_{13, \mathrm{k}} \mathrm{j}_{14,1} \\
\mathrm{j}_{21, \mathrm{k}} \mathrm{j}_{22, \mathrm{k}} \mathrm{j}_{23, \mathrm{k}} \mathrm{j}_{24,1} \\
\mathrm{j}_{31, \mathrm{k}} \mathrm{j}_{32, \mathrm{k}} \mathrm{j}_{33, \mathrm{k}} \mathrm{j}_{34,1} \\
\mathrm{j}_{41,1} \mathrm{j}_{42,1} \mathrm{j}_{43,1} \mathrm{j}_{44,1}
\end{array}\right]\left[\begin{array}{l}
\mathrm{E}_{\mathrm{t}-\mathrm{k}} \\
\mathrm{Y}_{\mathrm{t}-\mathrm{k}} \\
\mathrm{ELP}_{\mathrm{t}-\mathrm{k}} \\
\mathrm{TR}_{\mathrm{t}-\mathrm{k}}
\end{array}\right] \\
& +\left[\begin{array}{l}
\psi_{1} \\
\psi_{2} \\
\psi_{3} \\
\psi_{4}
\end{array}\right]\left[\mathrm{ECT}_{\mathrm{t}-1}\right]+\left[\begin{array}{l}
\gamma_{1 \mathrm{t}} \\
\gamma_{3 \mathrm{t}} \\
\gamma_{4 \mathrm{t}}
\end{array}\right]
\end{aligned}
$$

$\mathrm{ECT}_{\mathrm{t}-1}$ is the lagged error-correction term. Residual terms, $\gamma_{t}$ 's are uncorrelated random disturbance term with zero mean and $\varphi^{\prime} s$ are parameters to be estimated. The direction of causality can be detected through the VECM of long-run cointegration. The VECM captures both the short-run and the long-run relationships. The long-run causal relationship can be established through the significance of the lagged ECTs in equations based on $t$ test and the short-run Granger causality is detected through the test of significance of $F$-statistics of Wald test of the relevant $\varphi$ coefficients on the first difference series. 


\section{RESULTS AND DISCUSSION}

The Autoregressive Distributed Lag (ARDL) approach suggested by Pesaran et al. (2001) is applicable for variables that are $\mathrm{I}(0)$ or $\mathrm{I}(1)$ or fractionally integrated. Therefore, the first step is to test each of the variables to determine their order of integration. The analysis begins by investigating the unit root test of variables using the augmented Dickey and Fuller (1981) ADF and Philips and Perron (1988) PP tests. In both tests the null hypothesis of the series has a unit root is tested against the alternative of stationarity. Table 2 summarizes the outcome of the ADF and PP unit root tests on the natural logarithms of the levels and the first differences of the variables. The results suggest that all the series are stationary in their first difference, indicating that they are integrated at order one I(1) hence validate the use of ARDL approach for cointegration (All the selected time series are integrated at order one therefore employing other cointegration approaches such as Johansen and Juselius (1990) is applicable also. But bounds testing approach of cointegration has been employed in this study due to its advantages. Some of its advantages are having better properties for small samples and assessing the short-run as well as the long-run effects of the independent variables on the dependent variable simultaneously).

The bounds testing approach of cointegration starts with the $F$-test to confirm the existence of cointegration between the variables. Several misspecification tests such as serial correlation, functional form, normality and heteroscedasticity are applied in order to find the imposed maximum lag. The optimum lags are selected relying on minimizing the Akaike Information Criterion (AIC). The maximum lag order two was set. With that maximum lag lengths setting, the ARDL $(1,2,2,0,2)$ model is selected using AIC. ARDL $(1,2,2,0,2)$ represents the ARDL model in which the $\mathrm{CO}_{2}$ emissions, income, square of income, electricity production from renewable sources and trade openness take the lag length 1,2, 2, 0 and 2, respectively.

Table 2. Unit root tests results

\begin{tabular}{|c|c|c|c|c|c|}
\hline \multirow[b]{2}{*}{ Variables } & & \multicolumn{2}{|c|}{ Augmented Dickey-Fuller test statistic } & \multicolumn{2}{|c|}{ Phillips-perron test statistic } \\
\hline & & $\begin{array}{l}\text { Constant } \\
\text { linear trend }\end{array}$ & Constant & $\begin{array}{l}\text { Constant } \\
\text { linear trend }\end{array}$ & Constant \\
\hline \multirow[t]{2}{*}{$\mathrm{E}$} & Level & -1.060 & -1.708 & -1.054 & -1.770 \\
\hline & First difference & $-5.920 * * *$ & $-5.859 * * *$ & $-5.900 * * *$ & $-5.853 * * *$ \\
\hline \multirow[t]{2}{*}{$\mathrm{Y}$} & Level & -0.837 & -1.375 & -0.825 & -1.619 \\
\hline & First difference & $-3.967 * * *$ & $-3.916 * *$ & $-4.000 * * *$ & $-3.916^{* *}$ \\
\hline \multirow[t]{2}{*}{$\mathrm{Y}^{2}$} & Level & -0.723 & -1.497 & -0.721 & -1.722 \\
\hline & First difference & $-4.030 * * *$ & $-3.956 * *$ & $-4.100 * * *$ & $-3.956 * *$ \\
\hline \multirow{2}{*}{ ELP } & Level & -2.340 & -2.965 & $-3.100 * *$ & -2.780 \\
\hline & First difference & $-3.633 * *$ & $-3.056^{*}$ & $-4.400 * * *$ & $-5.690 * * *$ \\
\hline \multirow[t]{2}{*}{ TR } & Level & -1.300 & 0.465 & -1.301 & -0.030 \\
\hline & First difference & $-3.072 * *$ & -2.800 & $-3.090 * *$ & -3.109 \\
\hline
\end{tabular}

$\alpha^{* * *}, * *$ and $*$ are 1,5 and10\% of significant levels, respectively. The optimal lag length was selected automatically using the Schwarz information criteria for ADF test and the bandwidth is selected using the Newey-West method for PP test. E indicates per capita carbon dioxide emissions in metric tons, Y indicates per capita real GDP in constant 2000 US\$ and ELP indicates per capita electricity production from renewable energy sources and TR indicates trade openness.

Table 3. The results of ARDL cointegration

\begin{tabular}{lllll}
\hline & $\begin{array}{l}\text { AIC } \\
\text { optimal lags }\end{array}$ & $\begin{array}{l}\text { F Statistic (AIC- } \\
\text { selected optimal lags) }\end{array}$ & $\begin{array}{c}\left(\mathrm{EC}_{\mathrm{t}-1}\right) \\
\text { (t-Ratio) }\end{array}$ & Result \\
\hline$\left[\mathrm{E} \mid \mathrm{Y}, \mathrm{Y}^{2}, \mathrm{ELP}, \mathrm{TR}\right]$ & $(1,2,2,0,2)$ & 0.32 & $-0.41(-6.93)^{* * * *}$ & Cointegartion \\
Critical Values for F-statistics & Lower I $(0)$ & Upper I(1) & \\
$1 \%$ & & 4.768 & 6.670 & \\
$5 \%$ & 3.354 & 4.774 & \\
$10 \%$ & 2.752 & 3.994 & \\
\hline
\end{tabular}

\# The critical values are obtained from Narayan (2005), Critical values for the bounds test: case III: unrestricted intercept and no trend.*** represent $1 \%$ level of significance. Two is the maximum lag imposed 
Table 4. Long-run estimation results

\begin{tabular}{lcc}
\hline Regressors & Coefficient & T-values \\
\hline $\mathrm{Y}$ & 22.08810 & $5.8140^{* * *}$ \\
$\mathrm{Y}^{2}$ & -1.25910 & $-5.5008^{* * *}$ \\
ELP & -0.10513 & $-3.3457^{* * *}$ \\
$\mathrm{TR}$ & -0.52464 & $-3.3084^{* * *}$ \\
$\mathrm{C}$ & -91.89070 & $-6.1013^{* * *}$ \\
Diagnostic test statistics & Test-stats & $\mathrm{p}$-Value \\
Serial correlation & 2.24430 & 0.1340 \\
Functional form & 0.91167 & 0.3400 \\
Normality & 2.36770 & 0.3060 \\
Heteroskedasticity & 0.10130 & 0.7500 \\
\hline
\end{tabular}

a. ARDL $(1,2,2,0,2)$ selected on the basis of AIC. *** represent $1 \%$ level of significance

Table 5. The result of short-run for the selected ARDL model

\begin{tabular}{lcc}
\hline Regressor & Coefficient & T-Statistic \\
\hline$\Delta \mathrm{Y}$ & 20.17920 & $1.9430^{*}$ \\
$\Delta(\mathrm{Y})^{2}$ & -1.11630 & $-1.7699^{*}$ \\
$\Delta \mathrm{ELP}$ & -0.14849 & $-2.9233^{* * *}$ \\
$\Delta \mathrm{TR}$ & -0.34460 & -1.5879 \\
$\Delta \mathrm{C}$ & -129.78860 & $-4.4188^{* * *}$ \\
$\mathrm{ECT}_{\mathrm{t}-1}$ & -0.41240 & $-6.9344^{* * *}$ \\
Diagnostic test statistic & & \\
R-squared & 0.72830 & \\
$\mathrm{~F}(8,19)$ & $10.42180^{* * * *}$ & \\
DW-statistic & 2.31840 & \\
\hline
\end{tabular}

e. ARDL $(1,2,2,0,2)$ selected on the basis of AIC. * ** and *** represent $10 \%, 5 \%$ and $1 \%$ level of significance, respectively. Dependent variable is $\mathrm{E}$

The results of cointegration in Table 3 show that the F-statistic is not greater than its upper bound critical value. However, we can conclude that cointegration is supported by the significantly negative coefficient obtained for $\mathrm{EC}_{\mathrm{t}-1}$ (Kremers et al., 1992). This term shows the speed of adjustment process to restore the equilibrium. The relatively high coefficients imply a faster adjustment process. The values of the coefficients of $\mathrm{EC}_{\mathrm{t}-1}(0.41)$ indicating that the variables will adjust to the long-run equilibrium in about 2.5 period following a short-run shocks.

After finding the cointegration relationship between variables we can estimate Equation 1 in order to find the long-run coefficients. Table 4 provides the long-run estimation results along with diagnostic test statistics.

The significant positive and negative coefficients of $\mathrm{Y}$ and $(\mathrm{Y})^{2}$ respectively, suggest an inverted U-shaped relationship between per capita $\mathrm{CO}_{2}$ emissions and per capita real GDP supporting the EKC hypothesis. This confirms that $\mathrm{CO}_{2}$ emissions increase with economic growth then reach a turning point and then starts to decline with higher level of economic growth. The turning point of per capita real income turned out to be around 8.77 which is higher than the highest value of real GDP (8.49) in our sample. This finding is consistent with those of Jalil and Mahmud (2009) which find the EKC's turning points outside the observed sample period in the case of China.

The long-run elasticity of carbon dioxide emissions per capita with respect to real GDP per capita is 22.092.52LY. The long-run elasticity of $\mathrm{CO}_{2}$ emissions with respect to electricity production from renewable sources is negative and statistically significant. The coefficient value of 0.11 suggests that a $1 \%$ increase in per capita electricity production from renewable sources leads to around $0.11 \%$ decrease in per capita $\mathrm{CO}_{2}$ emissions. This negative and significant coefficient for per capita electricity production from renewable sources on $\mathrm{CO}_{2}$ emissions is in line with findings of Iwata et al. (2010) who found negative coefficient for nuclear power generation with respect to $\mathrm{CO}_{2}$ emissions. The coefficient of TR in the long-run is negative which is in line with the study of Jalil and Mahmud (2009) for China. The elasticity of $\mathrm{CO}_{2}$ emissions with respect to trade openness is -0.52 which suggests that $1 \%$ increase in foreign trade will lead to around $0.5 \%$ decrease in per capita $\mathrm{CO}_{2}$ emissions in the long-run in Malaysia.

The diagnostic test statistics do not suggest the presence of any serial correlation and heteroskedasticity. The estimated model also passes the diagnostic tests of normality and functional form. The model was also tested for stability of the short and long-run coefficients by testing the CUSUM and CUSUMSQ tests. Figure $\mathbf{1}$ and 2 illustrate that the stability of coefficients are supported because the plots of both CUSUM and CUSUMSQ fall within the critical bounds of 5\% significance.

Table 5 provides the short-run estimation results in error-correction representation with some diagnostic tests. A positive and negative coefficient for GDP per capita and square of GDP per capita at $10 \%$ significance level support the validity of the EKC hypothesis in the short-run in Malaysia. The short-run elasticity of real GDP per capita with respect to $\mathrm{CO}_{2}$ emissions per capita is $20.18-1.1163 \mathrm{Y}$. The turning point of per capita real income is 9.04 , compared to the highest value of GDP which is 8.49 . In the case of developing countries the EKC's turning points may not be within the observed sample period (Iwata et al., 2010). Similar to the longrun, there is negative and significant coefficient for electricity consumption with respect to $\mathrm{CO}_{2}$ emissions. This implies that electricity production from renewable energy sources plays a significant role in decreasing $\mathrm{CO}_{2}$ emissions in both short and long-run in Malaysia. 


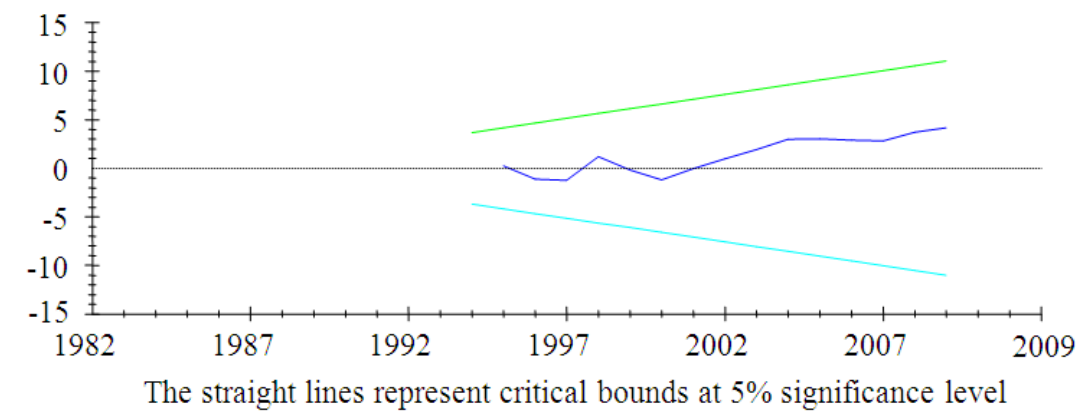

Fig. 1. Plot of cumulative sum of recursive residuals

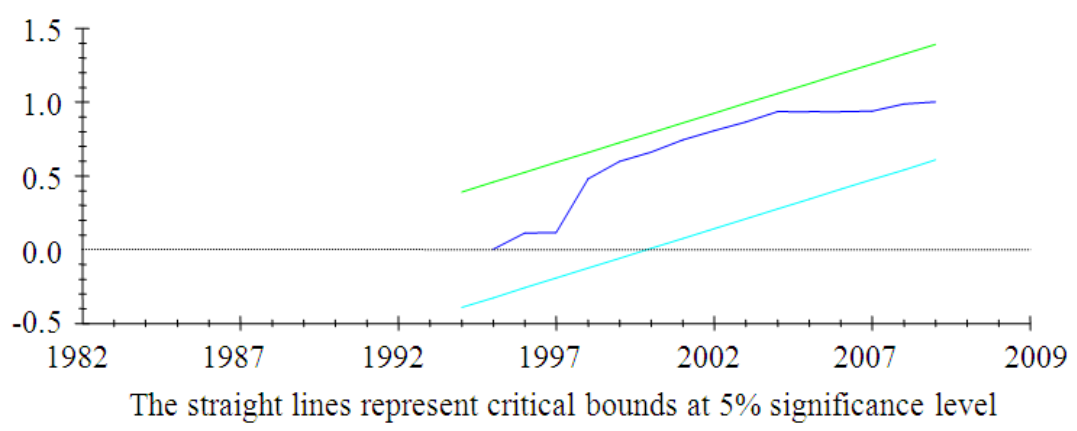

Fig. 2. Plot of cumulative sum squares of recursive residuals

Table 6. Granger causality results

Short Run Granger Causality F-statistics [prob]

\begin{tabular}{llllll} 
& $\Delta \mathrm{E}$ & $\Delta \mathrm{Y}$ & $\Delta \mathrm{ELP}$ & $\Delta \mathrm{TR}$ & \multicolumn{2}{l}{$\begin{array}{l}\text { Long run granger causality } \\
\mathrm{EC}_{\mathrm{t}-1}(\mathrm{t}-\mathrm{stats})\end{array}$} \\
\hline$\Delta \mathrm{E}$ & - & $(+) 14.49[0.0003]$ & $(-) 4.24[0.02]$ & $1.64[0.22]$ & $-0.94(-3.46)^{* * *}$ \\
$\Delta \mathrm{Y}$ & $(+) 7.82[0.01]$ & - & $2.31[0.12]$ & $1.47[0.26]$ & $-0.36(-2.004)^{*}$ \\
$\Delta \mathrm{ELP}$ & $1.65(0.22)$ & $1.59[0.23]$ & & $2.8[0.091]$ & $-0.51(-3.43)^{* * *}$ \\
$\Delta \mathrm{TR}$ & $0.71[0.51]$ & $0.35[0.71]$ & $1.08[0.36]$ & & $-0.2(-1.29)$ \\
\hline
\end{tabular}

f. Note: The null hypothesis is that there is no causal relationship between variables. Values in brackets are p-values for Wald tests with $\mathrm{F}$ distribution. $\mathrm{EC}_{\mathrm{t}-1}$ represents the error correction term lagged one period. The optimal lag is based on AIC. $\Delta$ represents the first difference

The coefficient of trade openness with respect to $\mathrm{CO}_{2}$ emissions is negative and insignificant. Insignificant coefficient of trade openness in the shot-run is in line with the findings of Jalil and Mahmud (2009) in the case of China, Nasir and Rehman (2011) and Shahbaz et al. (2012) for Pakistan.

The cointegration relationship between $\mathrm{CO}_{2}$ emissions per capita, real GDP per capita, electricity production per capita and trade openness implies the existence of causal relationship between the variables. In order to identify the casual relationship between the mentioned variables the Granger causality test based on VECM is employed.
The results of the causal relationship between the variables by using VECM based Granger causality test are summarized in Table 6. The results show that there are evidences of long-run bi-directional Granger causality relationships between economic growth and $\mathrm{CO}_{2}$ emissions and electricity production from renewable sources and $\mathrm{CO}_{2}$ emissions. Furthermore, the long-run causality shows a uni-directional causality running from trade openness to $\mathrm{CO}_{2}$ emissions. The short-run Granger causality results a bi-directional causality between economic growth and $\mathrm{CO}_{2}$ emissions and a negative unidirectional causality running from electricity production 
from renewable sources to $\mathrm{CO}_{2}$ emissions. Short and longrun bi-directional causal relationship between economic growth and $\mathrm{CO}_{2}$ emissions implies that carbon emissions and economic growth are highly interrelated to each other.

\section{CONCLUSION}

This study examines the short-run, long-run and casual relationship between $\mathrm{CO}_{2}$ emissions, economic growth, the potential of renewable energy sources and trade openness in Malaysia for the period 1980-2009. The Autoregressive Distributed Lag (ARDL) approach proposed by Pesaran et al. (2001) was chosen to examine the long and short-run relationship between the variables. The Granger causality test based on VECM was employed to test the casual relationship between the same variables. The empirical analysis reveals that there is a cointegration relationship between the selected variables. The significant positive and negative coefficients of $\mathrm{Y}$ and $(\mathrm{Y})^{2}$ respectively, suggest an inverted U-shaped relationship between per capita $\mathrm{CO}_{2}$ emissions and per capita real GDP supporting the EKC hypothesis in both short and long-run. This confirms that $\mathrm{CO}_{2}$ emissions increase with economic growth then reach a turning point and then starts to decline with higher level of economic growth. The elasticity of carbon dioxide emissions per capita with respect to real GDP per capita is $22.09-2.52 \mathrm{Y}$ and $20.18-1.1163 \mathrm{Y}$ in the long-run and short-run respectively.

The elasticity of $\mathrm{CO}_{2}$ emissions with respect to electricity production from renewable sources is negative and statistically significant in both short and long-run. This negative and significant coefficient for per capita electricity production from renewable sources on $\mathrm{CO}_{2}$ emissions is in line with findings of Iwata et al. (2010) who found negative coefficient for nuclear power generation with respect to $\mathrm{CO}_{2}$ emissions. The coefficient of TR in the long-run is negative which is in line with the study of Jalil and Mahmud (2009) for China. The elasticity of $\mathrm{CO}_{2}$ emissions with respect to trade openness is -0.52 which suggests that $1 \%$ increase in foreign trade will lead to around $0.5 \%$ decrease in per capita $\mathrm{CO}_{2}$ emissions in the long-run in Malaysia.

However the coefficient of trade openness with respect to $\mathrm{CO}_{2}$ emissions is negative and insignificant in the short-run and this concurs with the findings of Jalil and Mahmud (2009) in the case of China, Nasir and Rehman (2011) and Shahbaz et al. (2012) for Pakistan. The diagnostic test statistics do not suggest the presence of any serial correlation and heteroskedasticity. The estimated model also passes the diagnostic tests of normality and functional form. We tested the stability of the short and long-run coefficients by testing the CUSUM and CUSUMSQ tests. The stability of the variables in the estimated models suggests that all the estimated models are stable over the study period.

The Granger causality test indicates that there are evidences of long-run bi-directional Granger causality relationships between economic growth and $\mathrm{CO}_{2}$ emissions and electricity production from renewable sources and $\mathrm{CO}_{2}$ emissions. Furthermore, the long-run causality shows a uni-directional causality running from trade openness to $\mathrm{CO}_{2}$ emissions. The short-run Granger causality results a bi-directional causality between economic growth and $\mathrm{CO}_{2}$ emissions and a negative unidirectional causality running from electricity production from renewable sources to $\mathrm{CO}_{2}$ emissions. Short and longrun bi-directional causal relationship between economic growth and $\mathrm{CO}_{2}$ emissions implies that carbon emissions and economic growth are highly interrelated to each other.

The results imply the importance of renewable energy in controlling $\mathrm{CO}_{2}$ emissions in both short and long run in Malaysia. Renewable energy can ensure sustainability of electricity supply and at the same time can reduce $\mathrm{CO}_{2}$ emissions. Besides all the positive impacts of renewable energy sources on economic and environment and the Malaysian government efforts and investment in development of renewable sources consumption, the progress in consumption of renewable energy in the country has been slow. Therefore there is a serious need of policies to promote the consumption of renewable sources and also to bring public awareness to the importance of renewable sources in sustainability of energy in country.

\section{REFERENCES}

Akbostanci, E., S. Turut-Asik and G. Tunc, 2009. The relationship between income and environment in Turkey: Is there an environmental kuznets curve? Energy Policy, 37: 861-867. DOI: 10.1016/j.enpol.2008.09.088

Altinay, G. and E. Karagol, 2005. Electricity consumption and economic growth: Evidence from Turkey. Energy Econ., 27: 849-856. DOI: 10.1016/j.eneco.2005.07.002

Asafu-Adjaye, J., 2000. The relationship between energy consumption, energy prices and economic growth: Time series evidence from Asian developing countries. Energy Econ., 22: 615-625. DOI: 10.1016/S0140-9883(00)00050-5

Bruyn, S.M.D., J.C.J.M.V.D. Bergh and J.B.O. Schoor, 1998. Economic growth and emissions: Reconsidering the empirical basis of environmental Kuznets curves. Ecol. Econ., 25: 161-175. DOI: 10.1016/S0921-8009(97)00178-X 
Dickey, D.A. and W.A. Fuller 1981. Likelihood ratio statistics for autoregressive time series with a unit root. Econometrica, 49: 1057-1072.

Egli, H., 2004. The environmental Kuznets curve: Evidence from time series data for Germany. Institute of Economic Research.

Ferguson, R., W. Wilkinson and R. Hill, 2000. Electricity use and economic development. Energy Policy, 28: 923-934. DOI: 10.1016/S03014215(00)00081-1

Fodha, M. and O. Zaghdoud, 2010. Economic growth and pollutant emissions in Tunisia: An empirical analysis of the environmental Kuznets curve. Energy Policy, 38: 1150-1156. DOI: 10.1016/j.enpol.2009.11.002

Fried, B. and M. Getzner, 2003. Determinants of $\mathrm{CO}_{2}$ emissions in a small open economy. Ecol. Econ., 45: 133-148. DOI: 10.1016/S0921-8009(03)00008-9

Ghosh, S., 2002. Electricity consumption and economic growth in India. Energy Policy, 30: 125-129. DOI: 10.1016/S0301-4215(01)00078-7

Ghosh, S., 2010. Examining carbon emissions economic growth nexus for India: A multivariate cointegration approach. Energy Policy, 38: 2613-3130. DOI: 10.1016/j.enpol.2010.01.040

Granger, C.W.J., 1969. Investigating causal relations by econometric models and cross-spectral methods. Econometrica, 37: 424-38. DOI:10.2307/1912791

Grossman, G.M. and A.B. Krueger, 1991. Environmental impacts of a north american free trade agreement. NBER.

Halicioglu, F., 2009. An econometric study of $\mathrm{CO}_{2}$ emissions, energy consumption, income and foreign trade in Turkey. Energy Policy, 37: 1156-1164. DOI: 10.1016/j.enpol.2008.11.012

He, J. and P. Richard, 2010. Environmental Kuznets curves for $\mathrm{CO}_{2}$ in Canada. Ecol. Econ., 69: 10831093.

Holtz-Eakin, D. and T.M. Selden, 1995. Stoking the fires? $\mathrm{CO}_{2}$ emissions and economic growth. J. Public Econ., 57: 85-101. DOI: 10.1016/00472727(94)01449-X

Hossain, S., 2011. Panel estimation for $\mathrm{CO}_{2}$ emissions, energy consumption, economic growth, trade openness and urbanization of newly industrialized countries. Energy Policy, 39: 6991-6999. DOI: 10.1016/j.enpol.2011.07.042

Iwata, H., Okada, K. and S. Samreth, 2010. Empirical study on the environmental kuznets curve for $\mathrm{CO}_{2}$ in France: The role of nuclear energy. Energy Policy, 38: 4057-4063. DOI: 10.1016/j.enpol.2010.03.031
Jalil, A. and S.F. Mahmud, 2009. Environment kuznets curve for $\mathrm{CO}_{2}$ emissions: A cointegration analysis for China. Energy Policy, 37: 5167-5172. DOI: 10.1016/j.enpol.2009.07.044

Johansen, S. and K. Juselius, 1990. Maximum likelihood estimation and inference on cointegration-with applications to the demand for money. Oxford Bull. Econ. Stat., 52: 169-210. DOI: 10.1111/j.14680084.1990.mp52002003.X

Koh, M.P. and W.K. Hoi, 2002. Renewable energy in Malaysia: A policy analysis. Energy Sustain. Dev., 6: 31-39. DOI: 10.1016/S0973-0826(08)60323-3

Kraft, J. and A. Kraft, 1978. On the relationship between energy and GNP. J. Energy Dev., 3: 401-403.

Kremers, J.J., N.R. Ericson and J.J. Dolado, 1992. The power of cointegration tests. Oxford Bull. Econ. Stat., 54: 325-348. DOI: 10.1111/j.14680084.1992.tb00005.x

Lindmark, M., 2002. An EKC-pattern in historical perspective: carbon dioxide emissions, technology, fuel prices and growth in Sweden 1870-1997. Ecol. Econ., 42: 333-347. DOI: 10.1016/S09218009(02)00108-8

Masih, A.M.M. and R. Masih, 1997. On the temporal causal relationship between energy consumption, real income and prices: Some new evidence from Asian-energy dependent NICs Based on a multivariate cointegration/vector error-correction approach. J. Policy Model., 19: 417-440. DOI: 10.1016/S0161-8938(96)00063-4

Menyah, K. and Y. Wolde-Rufael, 2010. Energy consumption, pollutant emissions and economic growth in South Africa. Energy Econ., 32: 13741382. DOI: $10.1016 /$ j.eneco.2010.08.002

Narayan, P.K. and R. Smyth, 2005. Electricity consumption, employment and real income in Australia evidence from multivariate Granger causality tests. Energy Policy, 33: 1109-1116. DOI: 10.1016/j.enpol.2003.11.010

Narayan, P.K. and R. Smyth, 2009. Multivariate granger causality between electricity consumption, exports and GDP: Evidence from a panel of Middle Eastern countries. Energy Policy, 37: 229-236. DOI: 10.1016/j.enpol.2008.08.020

Narayan, P.K., 2005. The saving and investment nexus for China: Evidence from cointegration tests. Applied Econ., 37: 1979-1990. DOI: 10.1080/00036840500278103

Nasir, M. and F.U. Rehman, 2011. Environmental Kuznets Curve for carbon emissions in Pakistan: An empirical investigation. Energy Policy, 39: 18571864. DOI: 10.1016/j.enpol.2011.01.025 
Oh, W. and K. Lee, 2004. Causal relationship between energy consumption and GDP revisited: The case of Korea 1970-1999. Energy Econ., 26: 51-59. DOI: 10.1016/S0140-9883(03)00030-6

Ozturk, I. and A. Acaravci, 2010. $\mathrm{CO}_{2}$ emissions, energy consumption and economic growth in Turkey. Renew. Sustain. Energy Rev., 14: 3220-3225. DOI: 10.1016/j.rser.2010.07.005

Panayotou, T., 1993. Empirical Tests and Policy Analysis of Environmental Degradation at Different Stages of Economic Development. 1st Edn., ILO, Geneva, ISBN-10: 9221087964, pp: 27.

Pesaran, M.H. and B. Pesaran, 1997. Working With Microfit 4.0: Interactive Econometric Analysis. Oxford University Press, Oxford, ISBN-10: 0192685317, pp: 505.

Pesaran, M.H., Y. Shin and R.J. Smith, 2001. Bounds testing approaches to the analysis of level relationships. J. Applied Econ., 16: 289-326. DOI: 10.1002/jae.616

Philips, P. and P. Perron, 1988. Testing for a unit root in time series regression. Biometrica, 75: 335-346. DOI: $10.1093 /$ biomet $/ 75.2 .335$

Roca, J., E. Padilla, M. Farre and V. Galletto, 2001. Economic growth and atmospheric pollution in Spain: Discussing the environmental kuznets curve hypothesis. Ecol. Econ., 39: 85-99. DOI: 10.1016/S0921-8009(01)00195-1

Saboori, B., J. Sulaiman and M. Saidatulakmal, 2012. Economic growth and $\mathrm{CO}_{2}$ emissions in Malaysia: A cointegration analysis of the Environmental Kuznets Curve. Energy Policy, 51: 184-191. DOI: 10.1016/j.enpol.2012.08.065

Sari, R. and U. Soytas, 2009. Are global warming and economic growth compatible? Evidence from five OPEC countries? Applied Energy, 86: 1887-1893. DOI: 10.1016/j.apenergy.2008.12.007
Shafik, N. and S. Bandyopadhyay, 1992. Economic Growth and Environmental Quality: Time Series and Cross Country Evidence. World Bank Publications.

Shafik, N., 1994. Economic development and environmental quality: An econometric analysis. Oxford Econ. Papers, 46: 757-773.

Shahbaz, M., H. Lean and M.S. Shabbir, 2012. Environmental kuznets curve hypothesis in Pakistan: Cointegration and granger causality. Renew. Sustain. Energy Rev., 16: 2947-2953. DOI: 10.1016/j.rser.2012.02.015

Shiu, A. and P.L. Lam, 2004. Electricity consumption and economic growth in China. Energy Policy, 32: 47-54. DOI: 10.1016/S0301-4215(02)00250-1

Soytas, U. and R. Sari, 2003. Energy consumption and GDP: Causality relationship in G-7 countries and emerging markets. Energy Econ., 25: 33-37. DOI: 10.1016/S0140-9883(02)00009-9

Stern, D.I., 1993. Energy and economic growth in the USA: A multivariate approach. Energy Econ., 15: 137-150. DOI: 10.1016/0140-9883(93)90033-N

Wolde-Rufael, Y., 2004. Disaggregated industrial energy consumption and GDP: The case of Shanghai, 1952-1999. Energy Econ., 26: 69-75. DOI: 10.1016/S0140-9883(03)00032-X

Wolde-Rufael, Y., 2005. Energy demand and economic growth: The African experience. J. Policy Model., 27: 891-903. DOI: 10.1016/j.jpolmod.2005.06.003

Yoo, S., 2005. Electricity consumption and economic growth: Evidence from Korea. Energy Policy, 33: 1627-1632. DOI: 10.1016/j.enpol.2004.02.002

Zhang, X.P. and X.M. Cheng, 2009. Energy consumption, carbon emissions and economic growth in China. Ecol. Econ., 68: 2706-2712. DOI: 10.1016/j.ecolecon.2009.05.011 